\title{
Postanak života i kemijska kombinatorika
}

\section{N. Raos*}

Institut za medicinska istraživanja i medicinu rada, Ksaverska c. 2, 10000 Zagreb

\begin{abstract}
Sažetak
Prikazan je račun permutacija i varijacija na primjeru prebrojavanja kopolimera aminokiselina (peptida) i nukleotida (nukleinskih kiselina) zadane duljine i sastava. Golem broj mogućih biopolimera umjesto da ukazuje na nemogućnost (nasumičnog) postanka života iz nežive tvari, pokazuje baš suprotno: velik broj varijacija preduvjet je prirodnog odabiranja, koje je vodilo do evolucije prvih autonomnih sustava (protostanica) selektivnim procesima (katalitičke reakcije na mineralnim katalizatorima i sl.). Na temelju izloženog mogu se izvesti zadatci iz kemije, biologije i matematike, što je prikazano na nekoliko primjera.
\end{abstract}

\section{Ključne riječi}

Proteini, nukleinske kiseline, postanak života, kreacionizam, inteligentni dizajn, evolucija

\section{Uvod}

Postanak života na Zemlji ${ }^{1,2}$ čini se na prvi, i ne samo na prvi pogled za znanost nerješivim problemom: kako je jedna tako složena tvorba kao što je živa stanica mogla nastati sama od sebe, nasumičnom aglomeracijom molekula u praoceanu (ili u Darwinovoj "toploj barici")? ? $^{3}$ Toga su itekako svjesni kreacionisti, ili - kako se po novom zovu - zagovornici teorije "inteligentnog dizajna", ${ }^{* *}$ kada uspoređuju "slučajan" postanak života s nevjerojatnom mogućnošću nastanka zrakoplova nasumičnim slaganjem njegovih sastavnih dijelova i slično. ${ }^{4}$ Nakon razmatranja teorija o postanku života koje su kotirale početkom 20. stoljeća, biolog i franjevac Marijan Blažić (1897. - 1944.) kaže:

Zato su mnogi od njih [znanstvenika] pokušali, da umjetno stvaraju život u svojim laboratorijima i to pod najrazličitijim okolnostima. Upotrebiše sve i sva, počev od najneobičnijeg kemijskog spoja do ultraljubičastih i röntgenskih zraka. Neki su biolozi žrtvovali tim pokusima cijeli niz godina svog života; utrošene su velike svote novca; ispisane su mnoge knjige, a konačni je uspjeh bio savršeni neuspjeh... Oni nijesu bili sposobni ne samo da stvore sitnu travku ili malog crvića, nego ni nešto što bi sličilo živoj stanici. Njihovi pokusi bili su nova osuda samorodstva. ${ }^{5}$

\footnotetext{
*Dr. sc. Nenad Raos

e-pošta: raos@imi.hr

**Engleski izraz intelligent design najbolje bi bilo prevesti kao "promišljena namjera", no kako je u obliku "inteligentni dizajn" ušao u hrvatski jezik, treba ga kao takvog prihvatiti.
}

Neuspjeh tih i sličnih pokušaja da barem ponude racionalno objašnjenje kako je nastao život na Zemlji ${ }^{* * *}$ dovodi fra Blažića do neizbježnog zaključka (str. 90):

Svim tim teorijama jedno je zajedničko: strah od priznanja, da je Bog stvorio život. Oni naime tvrde, da stvaranje života znači čudo. A ne vide, da je ono što oni naučavaju još veće čudo, o kojem je poznati paleontolog Branca rekao: "Kad bi crkva tražila od nas, da takva šta vjerujemo, svi bi prirodoslovci zaprepašteni okrenuli leđa."

Iz svega rečenoga proizlazi jasno pitanje, jasan problem: kolika je vjerojatnost da je život nastao igrom slučaja? To je vrlo teško pitanje već zbog toga što je nemoguće sve stanične strukture podvrći pod isti matematički model. No mi možemo učiniti nešto jednostavnije i sustavnije, zapitat ćemo se koliko je moguće da neka određena biološka molekula, protein ili nukleinska kiselina nastane slučajno, nasumičnim povezivanjem njezinih monomernih jedinica. Tako dolazimo na temu kemijske kombinatorike, o kojoj je već bilo riječi u ovoj rubirici. ${ }^{7,8}$

\section{Račun permutacija i varijacija}

Do susreta učenika ili studenta s računom permutacija nužno dolazi kada se on suoči s problemom prebrojavanja

\footnotetext{
*** Toga su u to doba bili svjesni i materijalistički mislioci. Tako fiziolog Ivan Gjaja (Đaja) (1884. - 1957.) priznaje: "Šta nam ume nauka reći o poreklu života? Prvi je odgovor na to: ne zna se ništa", da bi odmah potom napisao: "Ali i onda kad se ništa ne zna, nauka nije nema. Jer se nauka ne bavi samo izvesnošću, nego i mogućnošću i verovatnošću. Preko mogućnosti i verovatnosti, t. j. preko hipoteze, dolazi se do istine" (ref. 6, str. 10).
} 
izomera peptida, proteina, nukleinskih kiselina ili općenito kopolimera. Dimer glicina i alanina ima dva izomera, GlyAla i Ala-Gly, za trimer $\{$ Gly, Ala, Cys $\}$ možemo pak napisati šest izomera: Gly-Ala-Cys, Gly-Cys-Ala, Ala-Gly-Cys, Ala-Cys-Gly, Cys-Gly-Ala i Cys-Gly-Ala. Jednostavno, riječ je o permutacijama bez ponavljanja, čiji se broj, $P_{n}$, računa prema formuli:

$$
P_{\mathrm{n}}=n !,
$$

gdje je $n$ broj elemenata skupa, a ! oznaka za faktorijele:

$$
n !=1 \cdot 2 \cdot 3 \ldots(n-1) \cdot n
$$

Očito, u prvom slučaju, $\{$ Gly, Ala $\}, P_{2}=2 !=2$, a u drugom, $\{$ Gly, Ala, Cys $\}, P_{3}=3 !=6$.

Za dulje peptidne lance broj permutacija dostiže astronomske iznose. Od pet različitih aminokiselina može se formirati već $5 !=120$ izomernih pentapeptida, a od deset aminokiselina više od tri milijuna $(10 !=3.628 .800)$. Suočen s takvim nevjerojatnim brojevima, Fran Bubanović zdvojno piše: "Odatle slijedi, da jamačno nikada ne ćemo moći sintetizirati onakov upravo protein, kakav se nalazi u prirodi!"9 Koliko je tek "jamačno" da takav protein nikad nije mogao nastati sam od sebe iz nežive tvari, igrom slučaja.

Račun permutacija bez ponavljanja staje međutim na broju 20, koliko ima proteinskih aminokiselina. Drugim riječima on nam kazuje da najveći peptid s aminokiselinama različite vrste ima $20 !=2.432 .902 .008 .176 .640 .000$ $\left(\approx 2,4 \cdot 10^{18}\right)$ izomera. No još više ima svih mogućih peptida te duljine. No da bismo odgovorili na pitanje koliko ih ima, moramo se poslužiti računom varijacija.

Odmah ćemo postaviti najizravnije pitanje: Koliko se peptida, duljine 200 aminokiselinskih ostataka, koliko su obično dugi peptidni lanci u proteinima, može napraviti od 20 prirodnih aminokiselina?

Evo odgovora. Imamo li dva skupa, J i G, od kojih prvi ima $k(J)$ a drugi $k(G)$ elemenata, onda u skupu njihovih uređenih parova $J \times G$ ima $k(J \times G)=k(J) \cdot k(G)$ elemenata. Primijenimo li navedeni princip na naš problem, najprije ćemo morati postulirati 200 identičnih skupova, koji svaki sadržava sve aminokiseline:

$A_{\mathrm{i}}=\{$ Gly, Ala, ... Phe, Tyr $\}, k\left(A_{\mathrm{i}}\right)=20, i=1,200$.

Iz toga slijedi da će skup svih polipeptida duljine 200 aminokiselinskih ostataka, $A$, imati

$$
k(A)=\Pi k\left(A_{\mathrm{i}}\right)=20^{200}=1,6 \cdot 10^{260}
$$

članova. To je broj koji je praktički nemoguće predočiti. Naime, broju $10^{100}$ dano je ime gogol (googol), ${ }^{10}$ kao najvećem broju koji još može imati nekog fizičkog smisla (u Suncu ima "samo" $10^{56}$ atoma).

Sličan proračun možemo provesti i za molekule nukleinskih kiselina, primjerice DNA. Sada skup gradimo od 5386 potpunih skupova nukleotida:

$$
N_{\mathrm{i}}=\{\mathrm{A}, \mathrm{T}, \mathrm{C}, \mathrm{G}\}, k\left(\mathrm{~N}_{\mathrm{i}}\right)=4, i=1,5386,
$$

pri čemu smo za primjer uzeli broj parova baza u bakteriofagu $\varphi$ X174, organizmu koji ima jedan od najkraćih genoma (genom čovjeka ima oko $3,3 \cdot 10^{9}$ parova baza). Iz toga nije teško izračunati:

$$
k(N)=\Pi k\left(N_{\mathrm{i}}\right)=4^{5386} \approx 10^{3246} .
$$

I bez ulaženja u analizu toga rezultata, jasno je da broj varijacija nukleotida (DNA, RNA) daleko nadmašuje broj varijacija proteina. Drugim riječima, već i najkraća molekula DNA ima potencijal kodiranja svih zamislivih proteina - i više od toga.

\section{Nužnost i slučajnost}

Razmatranje o mogućem broju proteina i nukleinskih kiselina definiranog sastava dovodi kemičara do spoznaje kako smo nakon sinteze milijuna organskih spojeva iskoristili tek neznatan dio mogućnosti što nam ih pruža priroda. Takvi proračuni pružaju međutim učenicima lijep primjer kako zakona kemijskog spajanja tako i primjene kombinatorike u kemiji. No što znače za biologa? Ti su proračuni slični onima koji pokazuju koliko treba vremena da potomstvo para zečeva premaši ljudsku populaciju ili da se od potomstva jedne muhe stvori metar debeo sloj kukaca preko čitavog planeta. Priroda ni izdaleka ne ostvaruje sve svoje potencijale, kako u razmnožavanju vrsta tako ni u broju proteina. Umjesto da to govori u prilog kreacionizmu, jer funkcionalni polipeptid (protein) nije mogao nastati "slučajno" (što je glavni argument protivnika teorije evolucije $\left.{ }^{4,11}\right)$, govori upravo suprotno (slika 1). Veliki brojevi, dobiveni računom permutacija i varijacija, ukazuju na selektivne procese koji odabiru održive entitete, bilo da je riječ o molekulama, stanicama, jedinkama ili vrstama. ${ }^{12}$ Da nije tako, zar "Inteligentni dizajner" ne bi inteligentnije dizajnirao živa bića i biomolekule?

I tu dolazimo do bitnoga: biološki sustavi su selektivni sustavi. Traženje hrane ili spolnog partnera temelji se na selekciji informacija. I metabolizam se temelji na selekciji, jer se i prepoznavanje molekula (receptora i liganda) temelji na selektivnom mehanizmu, modelu "ključa i brave". Stoga se za biokemijske procese može reći isto što i za sekvencije funkcionalnih polipeptida, tj. proteina: priroda iskorištava samo neizmjerno mali dio mogućnosti koje joj pruža kemija, odabire neizmjerno mali broj reakcija koje

\footnotetext{
* "Suprotno evoluciji, kada promatramo prirodu ne vidimo nove dijelove ili organe kako evoluiraju. Mnogi primjeri, kao što su oko i uho, tako su složeni da se čini nemogućim da su nastali slučajno. Te tvorbe nisu mogle nastati evolucijskim mehanizmom slučajnih mutacija koje su uvijek štetne, i prirodne selekcije koja nema mogućnosti planiranja unaprijed... Činjenice govore u prilog inteligentnog dizajna." (Ref. 11, str. 103). Argumenti su valjani samo (1) ako zanemarimo enormno mnogo vremena koliko život traje i razvija se na Zemlji i (2) ako zanemarimo selekcijske mehanizme u živoj prirodi. Oba su argumenta doktora Rotha, razumije se, šuplja. Drugi argument obrađujem u ovom članku, pa neću ovdje na njega trošiti riječi, a za prvi mogu reći da se čovjek iz perspektive dužine svojega života (100 godina) prema vremenu potrebnom za evoluciju vrste (tipično 10 milijuna godina) nalazi u istom položaju kao onaj tko hoće u jednoj minuti vidjeti kako zečevi dolaze na svijet. Ne bi li se i njemu činilo da zečevi dolaze niotkuda, da su nastali čudom Božjim?
} 


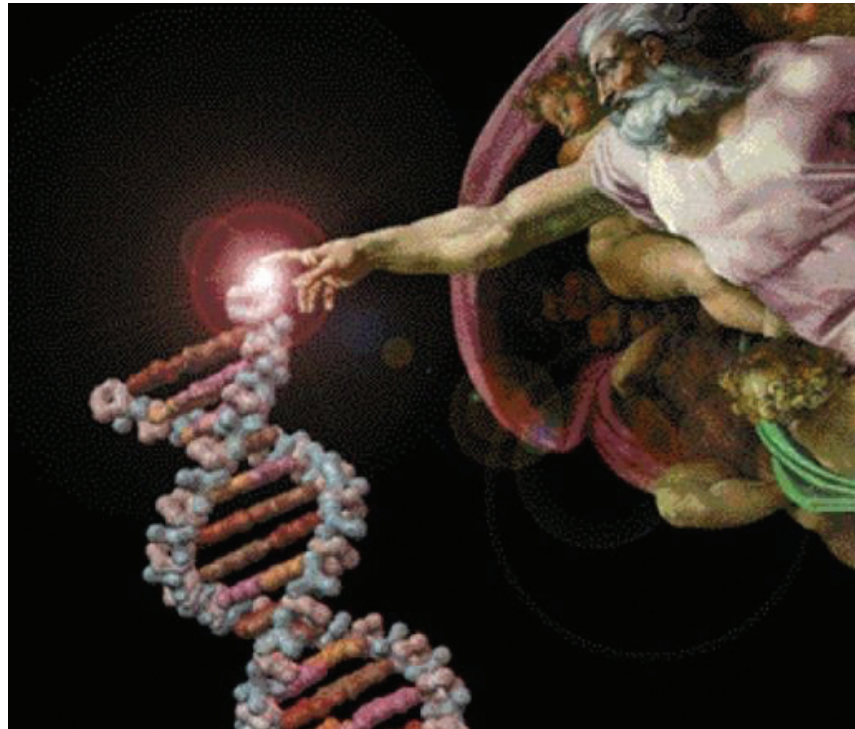

Slika 1 - Umjesto da govori u prilog inteligentnog dizajna, kompleksnost molekule DNA podržava teoriju evolucije. Samo nezamislivo velik broj mogućih nukleotidnih sekvencija (10 $10^{3246}$ za jednostavni genom bakteriofaga $\varphi$ X174) omogućuje selektivnost, koja ponovno vodi do razvoja funkcionalnog genoma.

Fig. 1 - Instead of speaking in favour of intelligent design, the complexity of the DNA molecule supports the theory of evolution. Only an enormous number of possible nucleotide sequences $\left(10^{3246}\right.$ for a simple phage $\varphi$ X174 genome) enables selectivity, leading to the development of a functional genome.

su moguće između komponenti žive stanice. S druge pak strane selektivnost bioreaktanata omogućava usklađenost i uređenost kemijskih reakcija u organizmu, što je - uređenost i usklađenost - temeljno svojstvo svega živoga ( $k o z-$ mos nasuprot kaosu).

Iz svega rečenoga slijedi neizbježan zaključak: ako se svekoliki život na Zemlji temelji na selektivnosti, onda su i procesi koji su do njega doveli bili selektivni. Kakvi su to procesi?

Prije svega katalitički. Jer iako je svaka kemijska reakcija selektivna (jer nijedna supstancija ne reagira sa svime), ka- talizatori povećavaju selektivnost, čemu su najbolji primjer upravo katalizatori biokemijskih reakcija, tj. enzimi. Stoga pitanje kako je nastao život na Zemlji treba svesti na pitanje kakvi su katalizatori postojali i kakve su reakcije katalizirali u doba kada na našem planetu još nije bilo života. Odgovor na to pitanje daju suvremena istraživanja: bili su to mineralni katalizatori, većinom minerali gline. ${ }^{13}$

Lijep primjer pruža nam polimerizacija nukleotida na mineralu gline montmorilonitu. ${ }^{14,15} \mathrm{U}$ reakciju ulaze monomeri RNA aktivirani imidazolom, ImpB, koji se potom polimeriziraju do lanaca s čak 50 monomernih jedinica ${ }^{16}$ (slika 2).

Polimeri (oligomeri) pojavljuju se u izomernim formama i s obzirom na diestersku vezu koja može biti tipa $3^{\prime}, 5^{\prime}$ ili $2^{\prime}, 5^{\prime}$. U slučaju da nema selektivnosti, svi bi polimeri nastajali $u$ istom iskorištenju koje bi opet bilo proporcionalno broju mogućih produkata. Reakcija se međutim pokazala selektivnom, i bez katalizatora, jer nastaje triput više veza $3^{\prime}, 5^{\prime}$ negoli veza $2^{\prime}, 5^{\prime} .{ }^{17,18}$ Kataliza montmorilonitom diže pak iskorištenje reakcije u sintezi nekih oligopeptida 15-struko (od 3,1 na $48 \%$ ), pa i 65-struko (od 0,2 na $13 \%)$, tablica 1.

Navedena sinteza oligonuleotida lijep je primjer kemijske kombinatorike. $U$ račun naime ne ulazi samo skup nukleotida, $N$, nego i skup veza, $B$, među njima, $B=\left\{3^{\prime}, 5^{\prime}, 2^{\prime}, 5^{\prime}\right\}$,

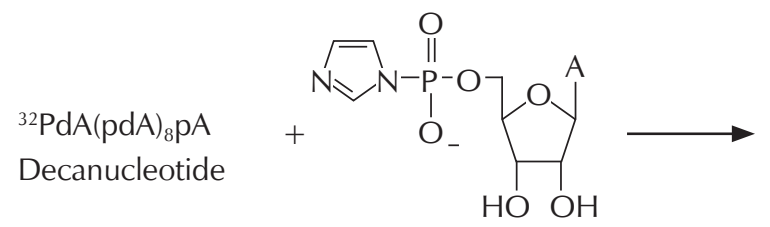

$$
\begin{aligned}
& { }^{32} \mathrm{PdA}(\mathrm{pdA})_{8} \mathrm{pApA} \stackrel{n \operatorname{ImpA}}{\longrightarrow}{ }^{32} \mathrm{PdA}(\mathrm{pdA})_{8} \mathrm{pA}(\mathrm{pA})_{n+1} \\
& +\operatorname{Im}
\end{aligned}
$$

Slika 2 - Prikaz reakcije polimerizacije ImpA na montmorilonitu kao katalizatoru

Fig. 2 - Scheme of the montmorillonite-catalysed ImpA polymerization reaction

Tablica 1 - Katalizirana sinteza polimera A i C iz aktiviranih nukleotida ImpA i ImpC na montmorilonitu ${ }^{14}$

Table 1 - Montmorillonite-catalysed synthesis of polymers A and C from activated nucleotides ImpA and ImpC ${ }^{14}$

\begin{tabular}{c|c|c|c|c}
\hline & \multicolumn{2}{|c|}{$\begin{array}{c}\text { Katalizirana sinteza } \\
\text { Catalysed synthesis }\end{array}$} & \multicolumn{2}{|c}{$\begin{array}{c}\text { Nekatalizirana sinteza } \\
\text { Random synthesis }\end{array}$} \\
\hline $\begin{array}{c}\text { Stupanj } \\
\text { polimerizacije } \\
\begin{array}{c}\text { Degree of } \\
\text { polymerization }\end{array}\end{array}$ & $\begin{array}{c}\text { Pronađeno } \\
\text { polimera } \\
\text { Polymers } \\
\text { observed }\end{array}$ & $\begin{array}{c}\text { Udjeli polimera } \\
\text { Proportion of } \\
\text { polymers } / \%\end{array}$ & $\begin{array}{c}\text { Predviđeno polimera } \\
\text { Polymers } \\
\text { predicted }\end{array}$ & $\begin{array}{c}\text { Iskorištenje po polimeru } \\
\text { Yield of each } \\
\text { polymer } / \%\end{array}$ \\
\hline 2 & 8 & $0,6-39$ & $2^{2} \cdot 2^{1}=8$ & 13 \\
3 & 10 & $1,1-48$ & $2^{3} \cdot 2^{2}=32$ & 3,1 \\
4 & 5 & $5,5-34$ & $2^{4} \cdot 2^{3}=128$ & 0,78 \\
5 & 4 & $4,3-13$ & $2^{5} \cdot 2^{4}=512$ & 0,20 \\
\hline
\end{tabular}


$k(B)=2$. Stoga se za skup polimera, $P$, nukleotida može napisati opći izraz:

$$
k(P)=\Pi k\left(N_{\mathrm{i}}\right) \Pi k\left(B_{\mathrm{j}}\right), j=i-1,
$$

koji za naš posebni slučaj, $k\left(N_{i}\right)=2$, poprima oblik:

$$
k(P)=2^{n} \cdot 2^{n-1},
$$

gdje je $n$ stupanj polimerizacije.

\section{Primjena u nastavi}

Prebrojavanje biopolimera određene duljine i sastava može se primijeniti u nastavi biologije, matematike i kemije. U biologiji pruža zoran primjer biološke selekcije dajući usto još jedan dokaz, tamo gdje ga učenik ne bi očekivao, o općem važenju zakona prirodnog odabiranja. U matematici daje materijal za vježbanje računa permutacija i varijacija. U kemiji ne samo da učenicima približava zakone kemijskog spajanja nego i pruža mogućnost postavljanja nestandardnih stehiometrijskih zadataka. ${ }^{19}$ Evo nekoliko takvih zadataka:

1. Kolika je masa molekula svih tetrapetida od četiri, pentapeptida od pet, heksapeptida od šest, itd. različitih aminokiselinskih ostataka, uz pretpostavku da se od svakog peptida sintetizira jedna molekula? Kada masa molekula dostiže jedan gram, a kada postaje veća od mase Zemlje $\left(m_{Z}=5,972 \cdot 10^{24} \mathrm{~kg}\right)$ ?

2. Kraći lanac molekule hemoglobina ( $\alpha$-lanac) ima 141 aminokiselinski ostatak. Koliko je točkastih mutacija toga lanca moguće? (U točkastoj mutaciji dolazi do zamjene jednog aminokiselinskog ostatka drugime).

3. Prema [GADV]-teoriji evolucije genskog koda ${ }^{20}$ prvi su proteini bili izgrađeni od samo četiri aminokiseline: glicina $(\mathrm{G})$, alanina $(\mathrm{A})$, asparaginske kiseline $(\mathrm{D})$ i valina (V). Koliko se proteinskih molekula $(n=100)$ može napraviti od te četiri aminokiseline? Koliki bi dio toga skupa zadovoljavao potrebe bakterijske stanice koja ima 3000 proteina?

4. Je li veći informacijski potencijal ljudskog ili biokemijskog jezika? Izračunajte broj mogućih riječi, uz pretpostavku da jezik ima 30, a riječ 5 slova. Usporedite to s brojem mogućih varijacija proteinskih sekvencija uz pretpostavku da se molekula sastoji od 100 aminokiselinskih ostataka.

5. Je li veća strukturna raznolikost, mjerena brojem izomera, oligopeptida ili alkana (vidi ref. 8)? Čime se može protumačiti razlika?

Osim zadavanja zadataka, kako bi učenici sami došli do odgovora na postavljena pitanja, nastavnik može upotrijebiti rezultate proračuna kako bi ilustrirao nastavno gradivo ukazujući na beskrajnu raznolikost živih bića, koja se opet temelji na raznolikosti biomolekula (DNA, RNA, proteina), vodeći na kraju do neizmjernog broja varijacija koje nam pružaju zakoni kemijskog spajanja.

\section{Literatura \\ References}

1. N. Raos, The Cookbook of Life - New Theories on the Origin of Life, Kemija u industriji/HDKI, Zagreb, 2018.

2. J. Peretó, Controversies on the origin of life, Int. Microbiol. 8 (2005) 23-31, doi: https://doi.org/10.1007/s0042500 50292.

3. J. Peretó, J. L. Bada, A. Lazcano, Charles Darwin and the origin of life, Orig. Life Evol. Biosph. 39 (2009) 395-406, doi: https://doi.org/10.1007/s11084-009-9172-7.

4. N. Raos, Revolucija evolucije: odgonetka postanka, Galaksija nova, 1. 5. 2018., URL: http://galaksijanova.rs/odgonetka-postanka/?script=lat.

5. M. Blažić, Osnovne pojave života. Pučka biologija. Jeronimska knjižnica, knjiga br. 632., Hrvatsko književno društvo sv. Jeronima, Zagreb, 1942., str. 88.

6. I. Gjaja, Biološki listići, Hrvatsko prirodoslovno društvo, Zagreb, 1918.

7. F. M. Brueckler, Kombinatorika u kemiji, Kem. Ind. 65 (7-8) (2016) 401-405, doi: https://doi.org/10.15255/ KUI.2016.010.

8. N. Raos, Kako prebrojati konstitucijske izomere alkana, Kem. Ind. 67 (3-4) (2018) 145-148, doi: https://doi.org/10.15255/ KUI.2017.055.

9. F. Bubanović, Kemija živih bića, Matica hrvatska, Zagreb, 1918., str. 154.

10. Hyper-E numbers, URL: https://sites.google.com/site/largenumbers/home/4-3/Hyper-E.

11. A. Rot, Postanje - povezivanje nauke i Biblije, Centar za prirodnjačke studije, Beograd, 2001. (A. A. Roth, Origins, Linking Science to Scripture, No limits books, 1998).

12. R. Pascal, A. Pross, The logic of life, Orig. Life Evol. Biosph. 46 (4) (2016) 507-513, doi: https://doi.org/10.1007/ s11084-016-9494-1.

13. N. Raos, V. Bermanec, Catalysis in the primordial world, Kem. Ind. 66 (11-12) (2017) 641-645, doi: https://doi. org/10.15255/KUI.2017.014.

14. J. P. Ferris, Montmorillonite-catalysed formation of RNA oligomers: the possible role of catalysis in the origins of life, Phil. Trans. Roy. Soc. B 361 (2006) 1777-1786, doi: https:// doi.org/10.1098/rstb.2006.1903.

15. S. Miyakawa, J. P. Ferris, Sequence- and regioselectivity in the montmorillonite-catalyzed synthesis of RNA, J. Am. Chem. Soc. 125 (2003) 8202-8208, doi: https://doi.org/10.1021/ ja034328e.

16. J. P. Ferris, A. R. Hill Jr., R. Liu, L. E. Orgel, Synthesis of long prebiotic oligomers on mineral surfaces, Nature 381 (1996) 59-61, doi: https://doi.org/10.1038/381059a0.

17. A. Kanavarioti, Dimerization in highly concentrated solutions of phosphorimizolide activated mononucleotides, Orig. Life Evol. Biosph. 27 (1997) 357-376, doi: https://doi. org/10.1023/A:1006526002896.

18. K. Kawamura, J. P. Ferris, Clay catalysis of oligonucleotide formation: kinetics of the reaction of the $5^{\prime}$-phosphorimidazolides of nucleotides with the non-basic heterocycles uracil and hypoxanthine, Orig. Life Evol. Biosph. 29 (1999) 563-591, doi: https://doi.org/10.1023/A:1006648524187.

19. N. Raos, Stehiometrija sa smislom, Kem. Ind. 66 (9-10) (2017) 531-535, doi: https://doi.org/10.15255/KUI.2017.002.

20. K. Ikehara, [GADV]-protein world hypothesis and the origin of life, Orig. Life Evol. Biosph. 44 (2014) 299-302, doi: https://doi.org/10.1007/s11084-014-9383-4. 


\section{SUMMARY}

\section{Origin of Life and Chemical Combinatorics \\ Nenad Raos}

The calculation of permutations and variations of biopolymers reveals an enormous number of possible structures of proteins and nucleic acids; there is about $10^{260}$ possible polypeptides of length 200 formed of 20 protein amino acids and $10^{3246}$ genomes with the same number of base pairs as the phage $\varphi$ X174 genome (5386 bp). Besides being a nice introduction into chemical combinatorics and combinatorics in general, such calculations provide an insight into the phenomenon of biological selectivity, as a general property of all living, from biomolecules to cells and species. Instead of being an argument in favour of intelligent design (because a functional, "live", protein molecule cannot be allegedly formed by "pure chance" among the myriads of non-functional ones), it is rather an argument against the origin of life by design. Namely, the enormous number of randomly synthesized molecules on early Earth had enabled selection processes that gradually led to more and more developed systems.

\section{Keywords}

Proteins, nucleic acids, origin of life, creationism, intelligent design, evolution

Institute for Medical Research and

Occupational Health

Ksaverska c. 2

10000 Zagreb, Croatia

Professional paper

Received June 7, 2018 Accepted June 28, 2018

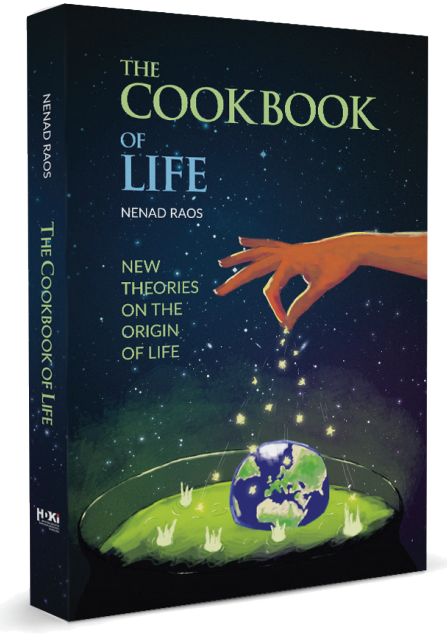

\section{THE COOK BOOK OF LIFE} (NEW THEORIES ON THE ORIGIN OF LIFE)

\author{
Dr. sc. Nenad Raos
}

Knjigu je moguće kupiti po cijeni od 150,00 kn

(PDV uključen).

Narudžbe se primaju telefonom (01/4872-499) ili elektroničkom poštom (hdki@zg.t-com.hr)

Studenti dobivaju $\mathbf{5 0} \%$ popusta uz predočenje indeksa, a članovi Društva $20 \%$.

NOVO!!! Amazon Kindle izdanje: POVEZNICA 